

\section{Think}

\section{Guidelines for Contributors}

The editor welcomes accessible contributions from philosophers and other thinkers on any topic broadly related either to philosophy or to the development of thinking skills. It is anticipated that most contributors will be academics.

Contributions should be below 4, ooo words (unless otherwise agreed with the editor). Very short pieces are welcome.

Think welcomes submissions which are clear and to the point and in the straightforward prose characteristic of the best philosophy. At the same time, the editor would also like to encourage the use of imaginative and unusual ways of making ideas engaging and accessible, e.g. through the use of dialogue, humour, illustrations (black and white: line and photos), examples taken from the media, etc. Papers engaging with some topical debate are especially welcome.

Contributors should presuppose no philosophical background knowledge on the part of the reader. The use of jargon and logical notation, especially where unexplained, should be avoided. Please avoid including notes and references if at all possible.

While the presentation of original thought is very much encouraged, a submission need not go beyond providing an engaging an accessible introduction to a particular philosophical issue or line of argument. Authors are asked to include within their submissions clear and fairly thorough introductions to any debates to which they wish to make a contribution.

Contributors of accepted articles will be asked to assign their copyright (on certain conditions) to the Royal Institute of Philosophy so that their interest may be safeguarded.

Authors are responsible for obtaining permission to reproduce any material for which they do not own copyright, to be used in both print and electronic media, and for ensuring that the appropriate acknowledgements are included in their manuscript.

The editor has the assistance of a panel of referees drawn from the Institute's Council. Please include with your contribution a brief statement of your position and institution (where relevant).

\section{Submissions}

Contributions (as Word documents) and communications should be sent to:

Stephen Law (editor)

THINK

Heythrop College

University of London

Kensington Square

London

W8 5 HQ

Email: think@royalinstitutephilosophy.org

\section{Format and Style}

The editor would be grateful if final submissions were in the Think house style. Please use single quotation marks (double when embedded). Please italicize rather than underline.

Where it is absolutely unavoidable that references be included, they should be incorporated into the text (preferably) or else appear as endnotes in the Think style. Examples:

Fred Author, Title of The Book (Place: Publisher, 2002), p. 23.

D. Academic, 'Title of Paper', A Journal, vol.I, no.I (I990), pp. 34-56. 


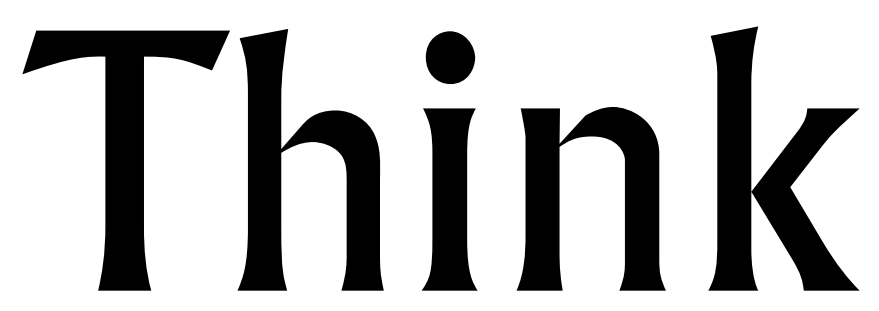

\title{
Philosophy for everyone
}

Number 38 • Autumn 2014

\author{
A Journal of \\ The Royal Institute of Philosophy
}

CAMBRIDGE
UNIVERSITY PRESS 


\section{Contents}

INTRODUCTION

Stephen Law

NEUROREDUCTIONISM ABOUT SEX AND LOVE

Julian Savulescu and Brian D. Earp

LIVING WELL

Steven M. Cahn and Christine Vitrano

IN DEFENSE OF THE SOCIAL SAFETY NET

Craig Duncan

A RESPONSE TO LAW AND MCBRAYER ON

39 HOMOSEXUAL ACTIVITY

Jack Mulder Jr.

BEYOND RETRIBUTION

Thom Brooks

A RESPONSE TO FORCEHIMES' 'DOWNLOAD THIS ESSAY: A DEFENCE OF STEALING EBOOKS' Sadulla Karjiker

HUMILITY AND HISTORY

lan James Kidd

TRANSIENT GLOBAL AMNESIA AND KANTIAN PERCEPTION

Stephen Hetherington

WHEN WORDS UNINTENTIONALLY WOUND:

A DUTY TO SELF-CENSOR

Ruth Tallman

USING HUMOROUS VIDEO CLIPS TO ENHANCE STUDENTS' UNDERSTANDING, ENGAGEMENT AND CRITICAL THINKING Mordechai Gordon 